\title{
Profiling of cell cycle genes of breast cells exposed to etodolac
}

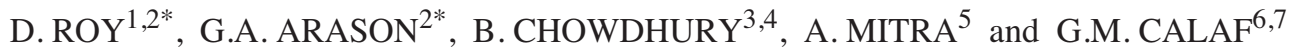 \\ ${ }^{1}$ Department of Natural Sciences, Hostos College of the City University of New York, Bronx, NY; ${ }^{2}$ Graduate Biotechnology \\ Program, Manhattan College, Riverdale, NY; ${ }^{3}$ Human Retrovirus Section, Vaccine Branch, National Cancer Institute, \\ National Institutes of Health, Frederick, MD; ${ }^{4}$ Department of Cellular Injury, Military Casualty Research, Walter Reed \\ Army Institute of Research, Silver Spring, MD; ${ }^{5}$ Department of Chemistry, The College of Mount Saint Vincent, \\ Riverdale, NY; ${ }^{6}$ Center for Radiological Research, Columbia University Medical Center, New York, NY, USA; \\ ${ }^{7}$ Instituto de Alta Investigación, Universidad de Tarapaca, Arica, Chile
}

Received September 29, 2009; Accepted November 6, 2009

DOI: $10.3892 /$ or_00000775

\begin{abstract}
Breast cancer represents the second leading cause of cancer-related deaths in the world. There is increasing evidence that perturbation of cell cycle regulation is an important contributing factor to various cancer progression stages. There are key checkpoints in the cell cycle involving various regulatory proteins. The relationship between these cell cycle regulatory proteins and cell cycle arrest by cyclooxygenase (COX) inhibitors during neoplastic progression remains largely unknown. Preclinical studies and epidemiological investigations have consistently shown that nonsteroidal anti-inflammatory drugs have some anti-proliferative and anti-oxidative stress response on various tumors. In this study, the effect of etodolac, a 1,8-diethyl-1,3,4,9-tetrahydropyrano $(3,4-\beta)$ indole- 1 -acetic acid on signaling pathways was investigated by examining the differential expression of various cell cycle regulatory protein genes. A human cell cycle gene array was used to profile the expression of 96 genes involved in the cell cycle regulation. Differentially expressed genes were highly altered by etodolac treatment. Twenty-six genes were up- and 20 down-regulated with 0.5 and $2 \mathrm{mM}$ etodolac treatment, respectively. Seven genes (ATM, BAX, CCNA2, CDC27, RAD50 and p21) were prominently altered, and six (ATM, CCND2, CCNF, CDC20, CDK1A and RAD50) were commonly altered with both concentrations. This finding indicated that etodolac could play a critical role on cancer cells by inducing cell death.
\end{abstract}

Correspondence to: Dr Debasish Roy, Department of Natural Sciences, The City University of New York, Hostos College Campus, no. A-507E, 475 Grand Concourse, Bronx, NY 10451, USA

E-mail: droy@hostos.cuny.edu

*Contributed equally

Key words: cell cycle, breast cells, etodolac

\section{Introduction}

Breast cancer represents the second leading cause of cancerrelated deaths in the United States and other Western countries; accounting for about $30-40 \%$ of all newly diagnosed cancers $(1,2)$. Hereditary breast cancer accounts for just $5-10 \%$ of cases. It is generally believed that a family history of breast cancer and hormonal imbalances also contributes to the development of breast cancer $(3,4)$. The etiology of breast cancer remains unknown, however, a profound and diverse number of factors including developmental, genetic, nutrition, chemotherapy, hormones, the environment and other yet undetermined factors have been implicated as risk factors for mammary tumorigenesis (5-8).

The malignant breast cell phenotype develops as a result of a multi-step process, requiring multiple genetic mutations (9-12). These mutations contribute to a cell that is increasingly characterized by uncontrolled proliferation, deregulated production of growth factors, non-responsiveness to extracellular anti-proliferative signals, anchorage independence, metastatic potential and resistance to antineoplastic agents. Recent advances in the molecular biology of breast cancer have identified various genes associated with tumorigenesis $(13,14)$. The development and progression of neoplastic transformation and the experimental reversal of tumorigenicity are accompanied by complex changes in patterns of gene expression. Complicated events are required for normal cells to change their behavior and these events involve the interaction between genes and possible environmental factors such as repeated exposure to ultraviolet light, irradiation, chemical pollutants, diet, chemotherapy, tobacco, alcohol among others. These factors seem to modulate the transformation of genes associated with the cell cycle pathway (12-15). Another potential mechanism through which genetic alterations may occur requires that the cellular DNA replication process becomes error prone. An increase in the error frequency associated with the DNA synthetic machinery responsible for elongating the DNA could lead to an accumulation of mutations (5).

There is increasing evidence that perturbation of cell cycle regulation is an important contributing factor to various cancer progression stages. There are two key checkpoints in 
the cell cycle, the $\mathrm{G}_{1}-\mathrm{S}$ and $\mathrm{G}_{2}-\mathrm{M}$ involving various regulatory proteins $(16,17)$. At present, the relationship between these cell cycle regulatory proteins and cell cycle arrest by cyclooxygenase (COX) inhibitors during neoplastic progression remains largely unknown. COX, also known as PGHS (prostaglandin $\mathrm{G} / \mathrm{H}$ synthase), is a key enzyme in catalyzing the conversion of AA (arachidonic acid) to PGs (prostaglandin) and other eicosanoids. Two isoforms of COX, COX-1 and COX-2 have been identified in different tissues. COX-1 is responsible for generating $\mathrm{PGs}$ for normal physiological function, whereas COX-2 is an early gene, which is rapidly induced by a variety of agents, including lipopolysaccharides, cytokines, growth factors and tumor promoters. Many studies have consistently showed that mRNA and protein levels of COX-2, but not COX-1, are markedly elevated during various neoplastic progressions (18).

Preclinical studies and early epidemiological investigations have consistently shown that non-steroidal antiinflammatory drugs (NSAIDs) have some anti-proliferative and anti-oxidative stress response on various tumors, including breast, colon and many other types of malignancies $(19,20)$. They act either by blocking cyclooxygenase (Cox) enzyme activity, thus inhibiting the conversion of arachidonic acid to prostaglandins or by induction of apoptosis and/or cell-cycle arrest $(21,22)$. Among the various NSAIDs, therefore, these agents appear to be an attractive option for cancer chemoprevention, which involves prevention/rectification of altered expression of cell cycle regulatory proteins. Most studies on etodolac have been performed with various human colon and other carcinoma cell lines and few of them focus on nonmalignant proliferative human mammary epithelial cell lines related to cell growth and cell cycle parameters (23-25). Laboratory experiments with various cancer cell lines reveal that etodolac induced a significant reduction in gastrointestinal cancer cell line Caco2, HT29 and MKN45 due to COX-2 inhibition. Inhibition of cell division and alteration of the cell cycle distribution were observed in cultured colon cancer cells, tumor cells were arrested in $G_{0} / G_{1}$ phase, and finally undergoing apoptosis. Furthermore, etodolac was found to inhibit COX-2 associated $\mathrm{PGE}_{2}$ synthesis in HT-29/Inv3 cell lines $(26,27)$. In this study, the effect of the NSAID, etodolac, a 1,8-diethyl-1,3,4,9-tetrahydro-pyrano $(3,4-\beta)$ indole-1-acetic acid (Fig. 1) on signaling pathways was investigated by examining the differential expression of various cell cycle regulatory protein genes.

\section{Materials and methods}

Cell line. The spontaneously immortalized mammary epithelial cell line MCF-10F (ATCC, Manassas, VA) was used in this study since it retains all the characteristics of normal epithelium in vitro, including anchorage dependence, noninvasiveness and non-tumorigenicity in nude mice (28-30). This cell line was cultured on Dulbecco's modified Eagle's media (DMEM)/F-12 (1:1) supplemented with $100 \mathrm{U} / \mathrm{ml}$ penicillin, $100 \mu \mathrm{g} / \mathrm{ml}$ streptomycin, $2.5 \mu \mathrm{g} / \mathrm{ml}$ amphotericin $\mathrm{B}, 10 \mu \mathrm{g} / \mathrm{ml}$ insulin (all from Life Technologies, Grand Island, NY), 5\% equine serum (Biofluids, Inc., Rockville, MD), $0.5 \mu \mathrm{g} / \mathrm{ml}$ hydrocortisone (Sigma Chemical Co., St. Louis, MO) and $0.02 \mu \mathrm{g} / \mathrm{ml}$ epidermal growth factor

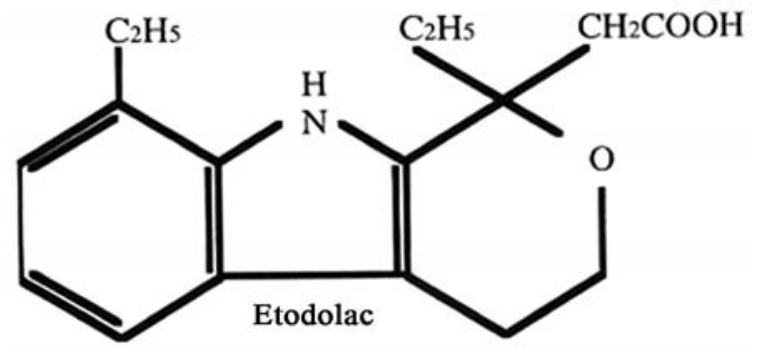

Figure 1. The chemical structure of etodolac: (1,8-diethyl-1,3,4,9tetrahydropyrano $(3,4-\beta)$ indole-1-acetic acid).

(Collaborative Research, Bedford, MA) (31). MCF-10F cell line was tested from time to time to ensure that it was free from any type of mycoplasma contamination.

Drug treatment. The MCF-10F cell line was treated with non-steroidal anti-inflammatory drug (NSAID) 1,8-diethyl$1,3,4,9$-tetrahydro-pyrano $(3,4-\beta)$ indole- 1 -acetic acid (etodolac) (Sigma Chemical Co.). Etodolac (143.7 mg) (Sigma Chemical Co.) was dissolved in $5 \mathrm{ml}$ of $0.01 \%$ DMSO solution. This stock solution $(1.5 \mathrm{ml})$ was exposed to $15 \mathrm{ml}$ of culture media to get $10 \mathrm{mM}$ concentration of etodolac (32). The culture medium was gently shaken immediately after addition to dissolve the drug solution uniformly. Then it was incubated at $37^{\circ} \mathrm{C}$ for $48 \mathrm{~h}$ with $5 \% \mathrm{CO}_{2}$. Medium was changed with the addition of fresh drug solution of the same concentrations after $24 \mathrm{~h}$ of incubation period. Only $0.01 \%$ DMSO solution (without addition of drug) was additionally used as the solvent control and allowed to grow for the same $48 \mathrm{~h}$ period with a change after $24 \mathrm{~h}$. Etodolac $(0.5$ and $2.0 \mathrm{mM}$ ) and $48 \mathrm{~h}$ growth period was chosen as an optimum activity considering other concentrations and growth periods (31). All experiments were done in duplicate and repeated at least three times with different adjacent passage of cell lines to obtain consistent results.

Isolation and purification of total RNA. Total RNA was isolated from both the control (MCF-10F) and the etodolac treated cell lines with TRIzol reagent (Invitrogen Corp., Long Island, NY). Each sample comprising $500 \mu \mathrm{g}$ of total RNA, was treated with $5 \mu 1$ of DNAse I $(10 \mathrm{U} / \mu \mathrm{l})$ (Boehringer Mannheim, Indianapolis, IN) for $60 \mathrm{~min}$ at $37^{\circ} \mathrm{C}$. Then $10 \mathrm{X}$ Termination Mix (0.1 M EDTA at $\mathrm{pH} 8.0$ and $1 \mathrm{mg} / \mathrm{ml}$ glycogen) (Clontech, Palo Alto, CA) was used to stop the reaction. Each sample was then purified following established procedure (31). The amount of each purified RNA sample was first measured by a spectrophotometer and then electrophoresed on denaturing formaldehyde/agarose/ethidium bromide gel, to check its quality and purity from proteins and free nucleotides.

cDNA expression array. GE Array Q Series Human p53 Signaling Pathway cDNA Expression Array membranes were purchased from SuperArray (Bethesda, MD). It is designed to profile gene expression of a panel of $96 \mathrm{key}$ genes involved in the $\mathrm{p} 53$ pathways $(33,34)$. They are grouped into two categories, one with p53 upstream signaling (sub- 
Table I. Functional gene grouping in a human cell cycle pathway gene array.

\begin{tabular}{ll}
\hline Gene grouping & \multicolumn{1}{c}{ Name of the genes } \\
\hline $\mathrm{G}_{1}$ phase & CCND1 (cyclin D1), CCND2 (cyclin D2), CCND3 (cyclin D3), CCNE1 (cyclin E1), \\
& CCNE2 (cyclin E2), CDC7L1, CDC34, CDC37, CDK2, CDK4, CDK6, CDKN1A (p21), \\
& CDKN1B (p27), CDKN1C (p57), CDKN2A (p16), CDKN2B (p15), CDKN2C (p18), \\
& CDKN2D (p19), CKS1, CKS2, CUL1, CUL2, CUL3, CUL4A, CUL4B, CUL5, E2F1, \\
& E2F2, E2F3, E2F4, E2F5, E2F6, NEDD8, RB1, RBL1 (p107 RB), RBL2 (p130 RB2), \\
& SKP1A, SKP2, TFDP1 (DP1), TFDP2 (DP2) \\
& CCNA1 (cyclin A1), CCNA2 (cyclin A2), CCNC (cyclin C), CCNG1 (cyclin G1), \\
& CCNG2 (cyclin G2), CCNH (cyclin H), CDC25A, CDC45L, CDC6, CDK7, CDK8, \\
S phase & MCM2, MCM3, MCM4 (CDC21), MCM5 (CDC46), MCM6 (Mis5), MCM7 (CDC47), \\
& MKI67 (Ki67), PCNA \\
& CCNB1 (cyclin B1), CCNB2 (cyclin B2), CCNF (cyclin F) \\
& CDC2 (CDK1), CDC16, CDC20 (p55cdc), CDC27, FOXM1 (MPP2), MAD2L1, \\
G phase & MAD2L2, PRC1, RBX1 \\
M phase & ABL1 (c-Abl), APAF1, ATM, BCL2, BAX, BRCA1, CHEK1 (chk1), CHEK2 (chk2, \\
& Rad53), GADD45A, HUS1, MDM2, MRE11A, MRE11B, NBS1 (nibrin), RAD9, \\
DNA damage checkpoint/ & RAD17, RAD50, RAD51, RPA3, TIMP3, TP53 (p53), UBC (ubiquitin C), UBE1, \\
p53 and ATM pathways & UBE3A (E6-AP), UBL1 (SUMO-1)
\end{tabular}

grouped as p53 expression and stability, p53 modification and p53 interactions) and the other with p53 downstream signaling (sub-grouped as cell-cycle control, apoptosis, DNA repair, angiogenesis and metastasis) $(34,35)$ (Table I). Each of these genes was amplified by polymerase chain reaction (PCR) with gene-specific primers, to generate 200- to 600-bp products. Approximately $100 \mathrm{ng}$ of each PCR product was spotted in quadruplicate onto a positively charged membrane.

Synthesis of cDNA probes from total RNA. The purified total RNAs were used for the synthesis of cDNA probes with Biotin-16-dUTP (Roche Pharm., Indianapolis, IN). Annealing mixture was prepared by mixing about $1.0-5.0 \mu \mathrm{g}$ of total RNA with $3 \mu$ l of Buffer A (GE primer mix) (SuperArray) and the final volume was adjusted to $10 \mu 1$. The mixture was then incubated in a preheated thermal cycler at $70^{\circ} \mathrm{C}$ for $3 \mathrm{~min}$. Cool to $42^{\circ} \mathrm{C}$ and kept at that temperature for $2 \mathrm{~min}$. Then $10 \mu \mathrm{l}$ of RT cocktail was prepared by mixing $4 \mu 1$ of $5 \mathrm{X}$ buffer BN [for $50 \mu 110 \mathrm{X}$ Buffer, add $1 \mu \mathrm{l}$ of $1 \mathrm{M}$ DTT and $50 \mu 1$ of $10 \mathrm{X}$ dNTP mix ( $5 \mathrm{mM}$ dATP, dCTP, dGTP and $500 \mu \mathrm{M}$ dTTP)], $2 \mu \mathrm{l}$ of Biotin-16-UTP, $2 \mu \mathrm{l}$ of RNase free $\mathrm{H}_{2} \mathrm{O}, 1 \mu \mathrm{l}$ of RNase inhibitor (Promega Corp., Madison, WI) and $1 \mu \mathrm{l}$ of MMLV reverse transcriptase (Promega Corp.). RT cocktail was then warmed to $42^{\circ} \mathrm{C}$ for 1 min and slowly mixed with $10 \mu 1$ of pre-warmed annealing mixture. Then incubation was continued at $42^{\circ} \mathrm{C}$ for $90 \mathrm{~min}$ and then labeled cDNA probe was denatured by heating at $94^{\circ} \mathrm{C}$ for 5 min, and quickly chilled on ice (36).

Differential hybridization of cDNA expression array. Each array membrane was pre-wetted with $5 \mathrm{ml}$ of de-ionized water and incubated at $60^{\circ} \mathrm{C}$ for $5 \mathrm{~min}$. It was then replaced with $2 \mathrm{ml}$ of pre-warm $\left(60^{\circ} \mathrm{C}\right)$ GEAprehyb solution (GEAhyb solution with a heat-denatured sheared salmon sperm DNA at a final concentration of $100 \mu \mathrm{g} / \mathrm{ml}$ ) (SuperArray) and mixed gently for few seconds. Pre-hybridization was continued at $60^{\circ} \mathrm{C}$ for $1-2 \mathrm{~h}$ with continuous gentle agitation. About $0.75 \mathrm{ml}$ solution of GEAhyb was prepared by adding the entire volume of denatured cDNA probe onto GEAprehyb solution and kept at $60^{\circ} \mathrm{C}$. Then GEAprehyb solution was replaced by GEAhyb solution and incubation continued overnight at $60^{\circ} \mathrm{C}$ with continuous gentle agitation. Subsequently, array membranes were washed twice in wash solution 1 ( $2 \mathrm{X}$ sodium chloride sodium citrate and $1 \%$ sodium dodecyl sulfate) at $60^{\circ} \mathrm{C}$ for 15 min each with gentle agitation and then twice with solution $2(0.1 \mathrm{X}$ sodium chloride sodium citrate and $0.5 \%$ sodium dodecyl sulfate) at $60^{\circ} \mathrm{C}$ for 15 min each with gentle agitation (36).

Chemiluminescent detection of cDNA probes. After discarding the last wash, $2 \mathrm{ml}$ of GEAblocking solution was added to each membrane and incubate for $40 \mathrm{~min}$ at room temperature with continuous agitation. Then binding buffer was prepared by diluting alkaline phosphatase-conjugated streptavidin (AP) with $1 \mathrm{X}$ Buffer F (SuperArray) in a 1:7500 dilution. Then GEAblocking solution was replaced by $2 \mathrm{ml}$ of binding buffer and incubated for $10 \mathrm{~min}$ with continuous but gentle agitation. Then membrane was washed four times with $4 \mathrm{ml}$ of $1 \mathrm{X}$ Buffer $\mathrm{F}$ for $5 \mathrm{~min}$ in each washing and twice with $3 \mathrm{ml}$ of buffer G (SuperArray). After that, membrane was covered with $1.0 \mathrm{ml}$ of CDP-Star chemiluminescent substrate and incubated at room temperature for 2-5 min. It was then exposed to X-ray film (Kodak BioMax MS Film; Kodak Corp., Rochester, NY) with corresponding intensifying 
Table II. Primers of differentially expressed genes selected for gene-specific RT-PCR analysis.

\begin{tabular}{|c|c|c|c|c|}
\hline GAN & Gene name & Product lengh $^{\mathrm{a}}(\mathrm{bp})$ & Map position & Primer sequence ${ }^{\mathrm{b}}$ \\
\hline NM_00O51 & $\mathrm{ATM}^{\mathrm{c}}$ & 500 & $11 q 22-q 23$ & $\begin{array}{l}\text { 1: 5'-ATCCTGCAAGTTTACCTAAC-3' } \\
\text { 1': 5'-GATCAGGGATATGTGAGTGT-3 }\end{array}$ \\
\hline X68452 & Cyclin D2 & 400 & $12 \mathrm{p} 13$ & $\begin{array}{l}\text { 1: 5'-CATGGAGCTGCTGTGCCACG-3' } \\
\text { 1': 5'-CCGACCTACCTCCAGCATCC-3' }\end{array}$ \\
\hline U17105 & Cyclin F & 400 & $10 q 12-q 13$ & $\begin{array}{l}\text { 1: 5'-GGTGTCTGACTACCCAGGTC-3' } \\
\text { 1': 5'-CATAGCATAGGAACGCTGCA-3 }\end{array}$ \\
\hline L47233 & p21Waf1 (p21Cip1) & 500 & $6 \mathrm{q} 21.2$ & $\begin{array}{l}\text { 1: 5'-GCCTGCCGCCGCCTCTTC-3' } \\
\text { 1': 5'-GCCGCCTGCCTCCTCCCAAC-3' }\end{array}$ \\
\hline U63139 & RAD 50 & 350 & $5 q 31$ & $\begin{array}{l}\text { 1: 5'-CTAAACTGCGACTTGCTCCA-3' } \\
\text { 1': 5'-TCTTACCTCATGGGCACAAG-3' }\end{array}$ \\
\hline NM_001255 & p55cdc (CDC20) & 380 & $6 \mathrm{q} 21.3-\mathrm{q} 21.5$ & $\begin{array}{l}\text { 1: 5'-CTCAGCGGCAAACCTCAGAA-3' } \\
\text { 1': 5'-ACTGGTTCCTCCTCCTGTTG-3' }\end{array}$ \\
\hline M10278 & B-actin & 250 & $7 \mathrm{p} 15-\mathrm{p} 12$ & $\begin{array}{l}\text { 1: 5'-GCGGGAAATCGTGCGTGACA-3' } \\
\text { 1': 5'-GATGGAGTTGAAGGTAGTTT-3' }\end{array}$ \\
\hline
\end{tabular}

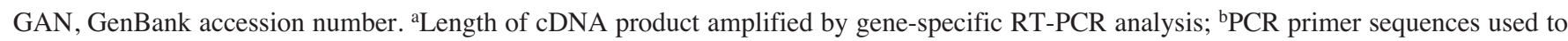
generate a product of the indicated size, listed in a 5'-3' orientation; 1 , forward; 1 ', reverse. ${ }^{\mathrm{c}}$ Ataxia telengiectasis mutated (include complementation group $\mathrm{A}, \mathrm{C}$ and $\mathrm{D}$ ).

screen at room temperature for multiple exposures of 1-5 min (36).

Quantification of array hybridization. Quantification of hybridization signals were carried out by exposing the X-ray film in a densitometer scanner (model 300A; Molecular Dynamics, Sunnyvale, CA). It was then estimated with the ImageQuant program (Molecular Dynamics). Volume quantification was performed by calculating the volume under the surface created by a three-dimensional plot of pixel locations and pixel values as described (36). To delineate the potential signal interference between adjacent strong hybridization signals, equal-sized ellipses were drawn around each signal area (hybridization spots) by using software (ImageQuant) and was then separately scanned and compared with housekeeping genes so the chances of interference between adjacent strong hybridization signals were minimized. Normalization of the expression levels of different housekeeping genes from multiple autoradiographic exposures between different hybridization experiments were done by taking the average signals of each of the housekeeping genes. Data from only higher concentration spots were used. Median background was subtracted, and signals that were $<1.5$-fold above background level were considered too low to accurately measure and were omitted from the analysis. Signals for each individual gene were also normalized to the geometric mean of the expression level of that gene across the set of membranes being compared. Mean signals were calculated from quadruplicate measurable spots, or if three of the four spots were measurable.
Construction of gene-specific primers. For gene-specific Reverse Transcription-Polymerase Chain Reaction (RT-PCR) and labeling of gene-specific probes, PCR primers (Genset Oligos, La Jolla, CA) were used to amplify the randomly selected 6 genes and human $\beta$-actin (Clontech) as a control amplifier set. Table II shows the base pair length of amplified cDNA of 6 genes under study and the sequence of sense and antisense primers to amplify those cDNAs (37).

Gene-specific RT-PCR analysis. To confirm differential expression of the 6 genes under study, gene-specific probes were generated by gene-specific RT-PCR technique (37). Different amounts of cDNAs and several PCR cycles were used to generate gene-specific probes. A linear increase was observed in product generation in all the cases. Based on the findings of this experiment, $100 \mathrm{ng}$ of cDNA was used and 35 cycles of PCR for amplification of the 6 genes by RT-PCR with an initial denaturation process at $94^{\circ} \mathrm{C}$ for $4 \mathrm{~min}$ followed by 35 cycles, each cycle comprising denaturation at $94^{\circ} \mathrm{C}$ for $30 \mathrm{sec}$, annealing at $65^{\circ} \mathrm{C}$ for $1 \mathrm{~min}$ and extension at $68^{\circ} \mathrm{C}$ for $1 \mathrm{~min}$ with a $5 \mathrm{~min}$ final extension at $68^{\circ} \mathrm{C}$. The PCR product was then run on a $1.2 \%$ agarose gel. Differentially expressed gene-specific DNA bands were then eluted from the gel and purified with the help of the QIAquick Gel Extraction kit (Qiagen, Inc., Valencia, CA). These genespecific DNA bands were used as a probe in Northern blot (37).

Northern blotting. About $500 \mu \mathrm{g}$ of total RNA was treated with $5 \mu \mathrm{l}$ of DNAse I (10 units/ $\mu$ l) (Boehringer Mannheim) for 


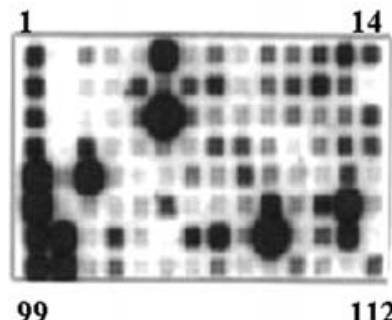

A

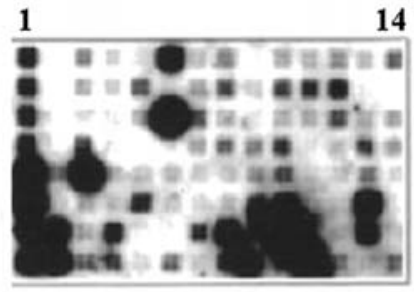

99

B

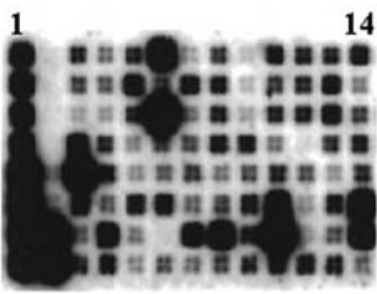

99

C

Figure 2. Analysis of human cell cycle cDNA expression array (A) control MCF-10F cell line; (B) MCF-10F exposed to 0.5 mM and (C) $2.0 \mathrm{mM}$ concentration of etodolac.

$60 \mathrm{~min}$ at $37^{\circ} \mathrm{C}$. The RNA was then extracted and precipitated using 7.5 M ammonium acetate, $\mathrm{pH} 5.2$ (32). A sample of $0.5-1 \mu \mathrm{g}$ of total RNA was then used for 1 st strand cDNA synthesis by using the Advantage ${ }^{\mathrm{TM}}$ RT-For-PCR kit (Clontech) using oligo(dT)18 and random hexamer primers. Approximately $100 \mathrm{ng}$ of the 1st strand cDNA synthesis product was used for carrying out RT-PCR reactions using gene specific primers as mentioned above. The PCR amplified products were then labeled by using respective primers and Biotin-16-UTP along with RT cocktail like before to generate the probes and then utilized for northern hybridization analysis. Total RNA $(10 \mu \mathrm{g})$ was also electrophoresed in a $1 \%(\mathrm{w} / \mathrm{v})$ agarose-formaldehyde gel, and transferred to a nylon membrane (Hybond-N, Amersham-Pharmacia Biotech, Piscataway, NJ). RNA transfer was confirmed by visualization of ethidium bromide stained RNA under UV light. Blots were UV crosslinked and stored at $4^{\circ} \mathrm{C}$ until hybridization. Human $\beta$-actin control amplifier set probe was also used in northern hybridization to confirm their similar expression in all the samples. The blot was then exposed to Kodak X-OMAT AR film at $-80^{\circ} \mathrm{C}$ for $24 \mathrm{~h}$. Intensity was assessed by densitometric scanning (Molecular Dynamics, NJ) $(36,37)$.

\section{Results}

In this study, the GEArray Q-series (Human Cell Cycle Gene array) was used to profile the expression of 96 genes involved in the cell cycle regulation. Several important genes were identified using this array. Altered expression of differentially expressed genes associated with different stages of cell cycle progression identified fell into the two main categories, the up-regulated group and the down-regulated group. Among them some genes were highly altered by the treatment with $0.5 \mathrm{mM}$ concentration of etodolac and some genes were altered by treatment with both 0.5 and $2 \mathrm{mM}$ concentration, 26 genes were up-regulated and 20 genes were down-regulated. Out of this number, ATM, BAX, CCNA2, CDC27, RAD50 and p21 were prominently altered, and ATM, CCND2, CCNF, CDC20, CDK1A and RAD50 were commonly altered in both concentrations. Among the genes commonly altered, six were further confirmed by Northern blot analysis in order to validate the results obtained from microarray gene expression (Fig. 2 and Table III).

Microarray technology allows us to measure the relative expression level of thousands of gene expressions in a single

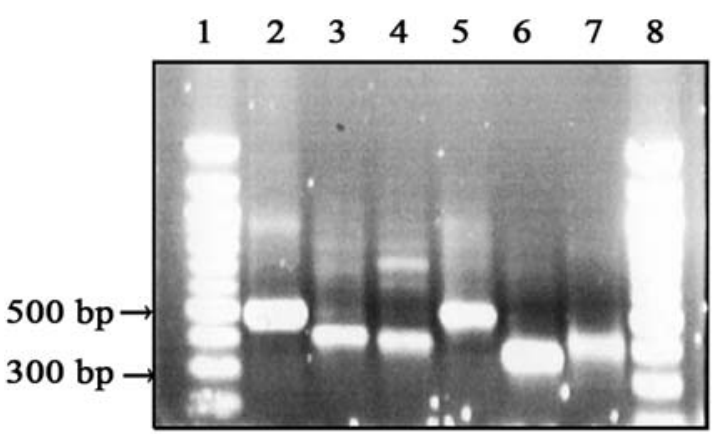

Figure 3. Gel electrophoresis pattern of six amplified gene fragments from gene-specific RT-PCR analysis required to generate gene-specific probes. 1 Marker, 100 bp DNA ladder; 2, ATM (500 bp); 3, cyclin D2 (400 bp); 4, cyclin F (400 bp); 5, p21Waf1 (p21Cip1) (500 bp); 6, RAD 50 (350 bp); 7, P55cdc (CDC20) (380 bp); 8 Marker, 100 bp DNA ladder.
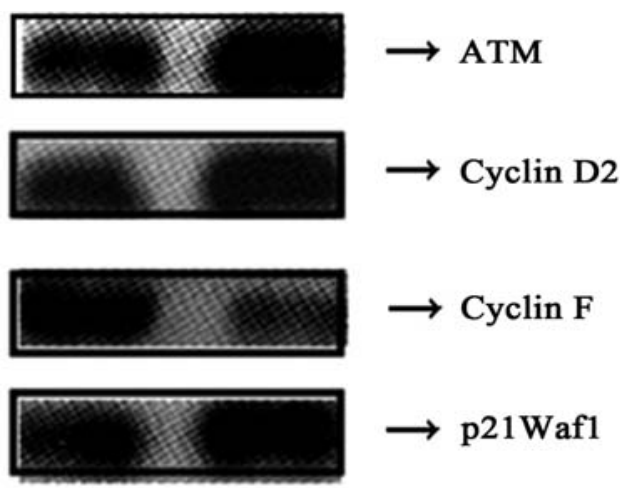

$\longrightarrow \mathrm{p} 21 \mathrm{Waf} 1$

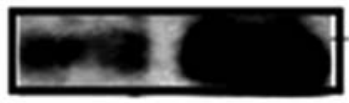

RAD50

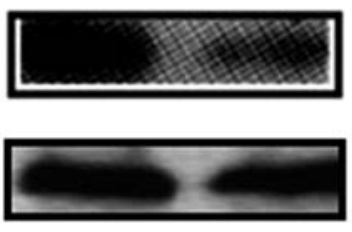

P55CDC

Figure 4. Northern blot analysis of gene-specific RT-PCR amplified fragments of six genes (ATM, cyclin D2, cyclin F, p21Waf1 (p21Cip1), RAD 50, p55cdc (CDC20) identified by differential hydridization of human cell cycle cDNA expression array exposed to both $(0.5$ and $2.0 \mathrm{mM})$ concentrations of etodolac.

experiment. In this study, the GEArray Q-series (Non Rad) Human Cell Cycle Gene array (SuperArray) was used to 
Table IIIA. Genes altered with $0.5 \mathrm{mM}$ concentration of etodolac.

\begin{tabular}{|c|c|c|c|c|c|}
\hline GeneBank & Gene name & $\begin{array}{l}\text { Gene } \\
\text { symbol }\end{array}$ & Description & $\begin{array}{l}\text { Gene } \\
\text { expression }\end{array}$ & $\begin{array}{l}\text { Position } \\
\text { in array }\end{array}$ \\
\hline NM_00051 & ATM & ATM & $\begin{array}{l}\text { Ataxia telengiectasis mutated } \\
\text { (include complementation group A, C and D) }\end{array}$ & Up-regulated & 3 \\
\hline X51688 & Cyclin A & CCNA2 & Cyclin A & Down-regulated & 8 \\
\hline M74091 & Cyclin C & $\mathrm{CCNC}$ & G1/S-specific cyclin C & Up-regulated & 11 \\
\hline X68452 & Cyclin D2 & CCND2 & Cyclin D2 & Down-regulated & 13 \\
\hline NM-004702 & Cyclin E2 & CCNE2 & Cyclin E2 & Up-regulated & 16 \\
\hline U17105 & Cyclin F & $\mathrm{CCNF}$ & Cyclin F & Down-regulated & 17 \\
\hline L49506 & Cyclin G2 & CCNG2 & Cyclin G2 & Up-regulated & 19 \\
\hline U11791 & Cyclin $\mathrm{H}$ & $\mathrm{CCNH}$ & Cyclin $\mathrm{H}$ & Up-regulated & 20 \\
\hline NM_001255 & $\begin{array}{l}\mathrm{p} 55 \mathrm{cdc} \\
(\mathrm{CDC} 20)\end{array}$ & $\mathrm{CDC} 20$ & $\mathrm{p} 55 \mathrm{cdc}$ & Down-regulated & 23 \\
\hline NM_001256 & $\mathrm{Cdc} 27$ & $\mathrm{CDC} 27$ & Cell division cycle 27 & Up-regulated & 25 \\
\hline L22005 & $\mathrm{CDC} 34$ & CDC34 & Ubiquitin-conjugating enzyme, cell division cycle 34 & Up-regulated & 26 \\
\hline U63131 & CDC37 & CDC37 & Cell division 37 , S. cerevisiae, homolog & Up-regulated & 27 \\
\hline U77949 & CDC6 & CDC6 & CDC6 cell division cycle 6 (S. cerevisiae) & Down-regulated & 29 \\
\hline NM_001799 & CDK7 & CDK7 & $\begin{array}{l}\text { Cyclin-dependent kinase } 7 \text { (homologof Xenopus } \\
\text { MO15 cdk-activating kinase) }\end{array}$ & Up-regulated & 34 \\
\hline X85753 & CDK8 & CDK8 & Cyclin-dependent kinase 8 & Down-regulated & 35 \\
\hline L47233 & $\begin{array}{l}\text { p21Waf1 } \\
\text { (p21Cip1) }\end{array}$ & CDKN1A & Cyclin-dependent kinase inhibitor 1A (p21, Cip1) & Down-regulated & 36 \\
\hline U10906 & p27Kip2 & CDKN1B & Cyclin-dependent kinase inhibitor 1B (p27, Kip1) & Up-regulated & 37 \\
\hline NM_003592 & Cul1 & CUL 1 & Cullin 1 & Up-regulated & 46 \\
\hline NM_003590 & Cullin-Cul3 & CUL3 & Cullin 3 & Up-regulated & 48 \\
\hline AF077188 & Cullin-ul4A & CUL4A & Cullin 4A & Up-regulated & 49 \\
\hline NM_003478 & Cullin-Cul5 & CUL5 & Cullin 5 & Up-regulated & 51 \\
\hline U47677 & E2F & E2F1 & E2F transcription factor 1 & Down-regulated & 52 \\
\hline U65410 & MAD2L1 & MAD2L1 & $\begin{array}{l}\text { MAD2 (mitotic arrest deficient, yeast, } \\
\text { homolog)-like } 1\end{array}$ & Up-regulated & 61 \\
\hline AF058696 & Nibrin & NBS1 & Nijimegen breakage syndrome 1 (nibrin) & Down-regulated & 73 \\
\hline U63139 & RAD50 & RAD50 & RAD50 (S. cerevisiae) homolog & Up-regulated & 78 \\
\hline D13804 & RAD51 & RAD51 & $\begin{array}{l}\text { RAD51 (S. cerevisiae) homolog } \\
\text { (E. coli RecA homolog) }\end{array}$ & Up-regulated & 79 \\
\hline M15400 & $\mathrm{Rb}$ & RB1 & Retinoblastoma 1 (including osteosarcoma) & Up-regulated & 82 \\
\hline NM_005611 & p130 (RB2) & RBL2 & Retinoblastoma-like 2 (p130) & Up-regulated & 84 \\
\hline NM_014248 & Rbx1 & RBX1 & Homo sapiens ring-box protein 1 (RBX1) mRNA & Up-regulated & 85 \\
\hline L23959 & DP1 & TFDP1 & $\begin{array}{l}\text { Homo sapiens E2F-related transcription } \\
\text { factor (DP-1) }\end{array}$ & Up-regulated & 89 \\
\hline NM_006286 & DP2 & TFDP2 & $\begin{array}{l}\text { Transcription factor Dp-2 (E2F } \\
\text { dimerization partner } 2)\end{array}$ & Up-regulated & 90 \\
\hline
\end{tabular}

B. Genes altered with $2 \mathrm{mM}$ concentration of etodolac.

\begin{tabular}{|c|c|c|c|c|c|}
\hline GeneBank & Gene name & $\begin{array}{c}\text { Gene } \\
\text { symbol }\end{array}$ & Description & $\begin{array}{l}\text { Gene } \\
\text { expression }\end{array}$ & $\begin{array}{l}\text { Position } \\
\text { in array }\end{array}$ \\
\hline NM_00O51 & ATM & ATM & $\begin{array}{l}\text { Ataxia telengiectasis mutated (include } \\
\text { complementation group A, C and D) }\end{array}$ & Down-regulated & 3 \\
\hline L22474 & bax & BAX & BCL2-associated X protein & Down-regulated & 4 \\
\hline M25753 & Cyclin B & CCNB1 & Cyclin B1 & Down-regulated & 9 \\
\hline NM_004701 & Cyclin B2 & CCNB2 & Cyclin B2 & Down-regulated & 10 \\
\hline
\end{tabular}


B. Continued.

\begin{tabular}{|c|c|c|c|c|c|}
\hline GeneBank & Gene name & $\begin{array}{l}\text { Gene } \\
\text { symbol }\end{array}$ & Description & $\begin{array}{l}\text { Gene } \\
\text { expression }\end{array}$ & $\begin{array}{l}\text { Position } \\
\text { in array }\end{array}$ \\
\hline X68452 & Cyclin D2 & CCND2 & Cyclin D2 & Up-regulated & 13 \\
\hline U17105 & Cyclin F & CCNF & Cyclin F & Down-regulated & 17 \\
\hline NM_001786 & $\operatorname{Cdk} 1(\operatorname{cdc} 2)$ & $\mathrm{CDC} 2$ & Cell div. cycle $2, G_{1}$ to Sand $G_{2}$ to $M$ & Down-regulated & 22 \\
\hline NM_001255 & $\begin{array}{l}\mathrm{p} 55 \mathrm{cdc} \\
(\mathrm{CDC} 20)\end{array}$ & CDC20 & p55cdc & Down-regulated & 23 \\
\hline L47233 & $\begin{array}{l}\text { p21Waf1 } \\
\text { (p21Cip1) }\end{array}$ & CDKN1A & $\begin{array}{l}\text { Cyclin-dependent kinase inhibitor } 1 \mathrm{~A} \\
\text { (p21, Cip1) }\end{array}$ & Up-regulated & 36 \\
\hline NM_001826 & Cks1p9 & CKS1 & CDC28 protein kinase 1 & Down-regulated & 44 \\
\hline NM_001827 & CKS2 & CKS2 & CDC28 protein kinase 2 & Down-regulated & 45 \\
\hline U74613 & MPP2 & FOXM 1 & $\begin{array}{l}\text { Human putative M phase phosphoprotein } 2 \\
\text { (MPP2) mRNA }\end{array}$ & Down-regulated & 58 \\
\hline X65550 & Ki67 (MKI67) & MKI67 & Antigen identified by monoclonal antibody Ki-67 & Down-regulated & 70 \\
\hline U63139 & RAD50 & RAD50 & RAD50 (S.cerevisiae) homolog & Up-regulated & 78 \\
\hline AB009010 & Ubiquitin $\mathrm{C}$ & $\mathrm{UBC}$ & Polyubiquitin & Up-regulated & 93 \\
\hline
\end{tabular}

C. Genes in common with both 0.5 and $2 \mathrm{mM}$ etodolac.

\begin{tabular}{llll}
\hline GeneBank & Gene name & $\begin{array}{c}\text { Gene } \\
\text { symbol }\end{array}$ & \multicolumn{1}{c}{$\begin{array}{l}\text { Description } \\
\text { Position } \\
\text { array }\end{array}$} \\
\hline NM_00051 & ATM & ATM & $\begin{array}{l}\text { Ataxia telengiectasis mutated (include complementation } \\
\text { group A, C and D) }\end{array}$ \\
X68452 & Cyclin D2 & CCND2 & Cyclin D2 \\
U17105 & Cyclin F & CCNF & Cyclin F \\
NM_001255 & p55cdc (CDC20) & CDC20 & p55cdc \\
L47233 & p21Waf1 & CDKN1A & Cyclin-dependent kinase inhibitor 1A (p21, Cip1) \\
U63139 & R21Cip1) & RAD50 & RAD50 (S. cerevisiae) homolog \\
\hline
\end{tabular}

profile the expression of 96 genes involved in the cell cycle regulation. Several important genes were identified using this array. Altered expression of the differentially expressed genes associated with different stages of cell cycle progression identified and fell into up-regulated and downregulated groups. Among them several genes were highly altered by the treatment at $0.5 \mathrm{mM}$ concentration of etodolac. A total of 26 genes were up-regulated and 20 genes were down-regulated, six of them were further confirmed by Northern blot analysis in order to validate the results obtained from microarray gene expression (Figs. 3 and 4).

\section{Discussion}

Microarray technology allows analyzing several gene expressions in a single experiment. Advancement in microarray technology and gene expression databases provides new opportunities for determination of mode of action and targets for the drugs. This feature allows researchers to characterize and analyze gene expression associated with a specific biological pathway in a more comprehensive manner. Breast cancer is one of the most common cancer forms affecting many women, and this occur due to alteration in various mechanisms that regulate the cell cycle. Defects in the $G_{1} / S$ transition in the cell cycle affect both tumor proliferation as well as checkpoints responsible for chromosomal integrity and DNA damage response. The cell cycle pathway has been the subject of extensive studies because various neoplasias show directly or indirectly deregulated cell cycle genes.

Targeting its regulatory molecules as a therapeutic mode to develop new anticancer drugs is being currently explored in both academia and by pharmaceutical companies. The development of new compounds is being focused on the many features of the cell cycle with promising preclinical data in most fields. Moreover, a few compounds have entered clinical trials with excellent results maintaining high hope. Although still too early to provide a cell cycle target based new commercial drug, there is no doubt that it will be an excellent source of new anticancer compounds (38). Many cell cycle regulatory proteins are either oncogenes or suppressor genes or are closely associated to the transformation process (39). 
In this study, the effects of etodolac a member of the NSAIDs, was investigated on the expression of genes involved in cell cycle regulation on MCF-10F cell line. Several important genes were identified and the altered expression of differentially expressed genes associated with different stages of cell cycle progression observed includes up-regulated and down-regulated genes. The precise mechanism by which NSAIDs inhibit tumorigenesis has often been attributed to the inhibition of arachidonic acid metabolism through the modulation of COX activity, which in turn affect cell proliferation or apoptosis in colonic and other tumors. There are, however, published reports of antineoplastic activities of NSAIDs that are independent of COX-1 and COX-2. Experimental evidence has now established that NSAIDs increased p27 (Kip1) by inhibiting protein degradation to suppress the proliferation of human lung cancer cells (40). In our experiment, a similar observation was made since after treatment of the MCF-10F cell line with $0.5 \mathrm{mM}$ concentration of etodolac, there was an up-regulation of p21(Kip1) gene. It has also been reported that NSAIDs inhibit proteosome activity to increase the p27(Kip1) protein level.

Studies on the effects of retinoic acids which are also promising agents for the prevention and treatment of several human malignancies including breast cancer reveal the mechanism of growth modulation on human lung squamous carcinoma $\mathrm{CH} 27$ cells. Report showed that retinoic acids mediated the dose- and time-dependent growth arrest in $\mathrm{G}_{1}$ phase accompanied by the up-regulation of p27(Kip1) and the down-regulation of the Cdk3 and p21(Waf1/Cip12) proteins (41). This study also confirmed such results, however, there was no significant change in the level of Cdk3 expression. This could be due to the fact that our experiment was performed with a normal breast epithelial cell line. This finding indicates that NSAIDs may also be strong candidates for the cell cycle regulators that prevent the entry into the $S$ phase with prolongation of $G_{1}$ phase and inhibition of DNA synthesis.

Treatment of MCF-10F cells with both concentrations of etodolac induced down-regulation of p55Cdc gene. The overexpression of p55cdc gene resulted in cell death in both HeLa and NIH3T3 cells in a dose-dependent manner. The present study with the MCF-10F cell line was in agreement with the above results.

Ataxia telangiectasia (ATM) has a tumor suppressor role in breast cancer. ATM appears to be expressed in most normal cells, including breast epithelium, where it has been postulated to have a nuclear role in cell cycle regulation following DNA damage. Although, ATM is not up-regulated after DNA damage, in this study it was observed both in upand down-regulation of the ATM gene. The downward regulation of ATM gene in normal breast epithelium may indicate that there are other factors than ATM gene mutation that dramatically influences the expression of ATM in the breast. These factors should be considered for further study and their possible implication in carcinogenesis (42). Several other important genes altered in our experiment have been observed in human tumors and postulated to contribute to the progression of tumor growth. This finding also indicated that etodolac could play a critical role if used on cancer cells including breast cancer by inducing cell death through the same mechanism by which taxol induced cell death in HeLa cells and NIH3T3 cells (43).

\section{Acknowledgements}

This study was conducted as part of a Master's Degree thesis (GAA) and it was funded by the Graduate Biotechnology Program of the Manhattan College of New York. Thanks are given to FONDECYT 1080482 (GMC), CUNY Research Release Time (DR). The secretarial assistance of Danissa Barahona is greatly appreciated. We also thank Convenio de Desempeño UTA/MESESUP2 from Universidad de Tarapacá, Arica, Chile.

\section{References}

1. Weir HK, Thun MJ, Hankey BF, et al: Annual report to the nation on the status of cancer, 1975-2000, featuring the uses of surveillance data for cancer prevention and control. J Natl Cancer Inst 95: 1276-1299, 2003.

2. Quinn MJ: Cancer trends in the United States - a view from Europe. J Natl Cancer Inst 95: 1258-1261, 2003.

3. Shaping the future of breast cancer: Awareness, Research, Diagnosis and Treatment. HHS Fact Sheet, 2000.

4. Pharoah PD, Day NE, Duffy S, Easton DF and Ponder BA: Family history and the risk of breast cancer: a systematic review and meta-analysis. Int J Cancer 71: 800-809, 1997.

5. Sekowski JW, Malkas LH, Schnaper L, Bechtel PE, Long BJ and Hickey RJ: Human breast cancer cells contain an errorprone DNA replication apparatus. Cancer Res 58: 3259-3263, 1998.

6. Devilee P and Cornelisse CJ: Somatic genetic changes in human breast cancer. Biochim Biophys Acta 1198: 113-130, 1994.

7. Alberg AJ, Singh S, May JW and Helzllsouer KJ: Epidemiology, prevention and early detection of breast cancer. Curr Opin Oncol 12: 515-520, 2000.

8. Roy D, Calaf G and Hei TK: Frequent allelic imbalance on chromosome 6 and 17 correlate with radiation-induced neoplastic transformation of human breast epithelial cells. Carcinogenesis 22: 1685-1692, 2001.

9. Knaus J: Functional results of total mesorectal excision for rectal cancer. Int J Surg Investig 1: 263-267, 1999.

10. Loeb LA: Mutator phenotype may be required for multistage carcinogenesis. Cancer Res 51: 3075-3079, 1991.

11. Paulson TG, Wright FA, Parker BA, Russack V and Wahl GM: Microsatellite instability correlates with reduced survival and poor disease prognosis in breast cancer. Cancer Res 56: 4021-4026, 1996.

12. Malkas LH and Hickey RJ: Expression, purification and characterization of DNA polymerases involved in papovavirus replication. Methods Enzymol 275: 133-167, 1996.

13. Pitot HC: The molecular biology of carcinogenesis. Cancer 72 (Suppl. 3): S962-S970, 1993.

14. Bieche I and Lidereau R: Genetic alterations in breast cancer. Genes Chromosomes Cancer 14: 227-251, 1995.

15. Liao MJ, Zhang CC, Zhou B, et al: Enrichment of a population of mammary gland cells that form mammospheres and have in vivo repopulating activity. Cancer Res 67: 8131-8138, 2007.

16. Silva JM, Marran K, Parker JS, et al: Profiling essential genes in human mammary cells by multiplex RNAi screening. Science 319: 617-620, 2008.

17. Zhang WH, Poh A, Fanous AA and Eastman A: DNA damageinduced $\mathrm{S}$ phase arrest in human breast cancer depends on Chk1, but G2 arrest can occur independently of Chk1, Chk2 or MAPKAPK2. Cell Cycle 7: 1668-1677, 2008.

18. Zhao C, Croswami M, Pookhniyal N, et al: Cyclooxygenase-2 expression during immortalization and breast cancer progression. Cancer Res 68: 467-475, 2008.

19. Steele V, Hawk ET, Viner JL and Lubert RA: Mechanisms and applications of non-steroidal anti-inflammatory drugs in the chemoprevention of cancer. Mutat Res 523-524: 137-144, 2003. 
20. Adachi M, Sakamoto H, Kawamura R, Wang W, Imai K and Shinomura Y: Non-steroidal anti-inflammatory drugs and oxidative stress in cancer cells. Histol Histopathol 22: 437-442, 2007.

21. Shen TY, Ham EA, Cirillo VJ, et al: Prostaglandin synthetase inhibitors. In: Prostaglandin Synthetase Inhibitors. Their Effects on Physiological Functions and Pathological States. Robinson HJ and Vane JR (eds). Raven Press, New York, pp18-31, 1974.

22. Sato TA, Keelan JA and Mitchell MD: Regulation of prostaglandin production in an immortalized human myometrial cell line by cytokines and non-steroidal anti-inflammatory drugs. Eur J Obstet Gynecol Reprod Biol 100: 158-162, 2000.

23. Jones RA: Etodolac: an overview of a selective COX-2 inhibitor. Inflammopharmacol 7: 269-275, 1999.

24. Yamazaki R, Kusunoki N, Matsuzaki T, Hashimoto S and Kawai S: Selective cyclooxygenase-2 inhibitors show a differential ability to inhibit proliferation and induce apoptosis of colon adenocarcinoma cells. FEBS Lett 531: 278-284, 2002.

25. Gallicchio L, McSorley M, Newschaffer CJ, Thuita L, Huang HY, Hoffman S and Helzisouer K: Non-steroidal antiinflammatory drugs, cyclooxigenase polymorphisms and the risk of developing breast carcinoma among women with benign breast disease. Am Cancer Soc 106: 1443-1452, 2006.

26. Micklewright R, Lane S, Linley W, McQuade C, Thompson F and Maskrey N: Review article: NSAIDs, gastroprotection and cyclo-oxygenase-II-selective inhibitors. Aliment Pharmacol Ther 17: 321-332, 2003.

27. Noda M, Tatsumi Y, Tomizawa M, et al: Effects of etodolac, a selective cyclooxygenase-2 inhibitor, on the expression of E-cadherin-catenin complexes in gastrointestinal cell lines. J Gastroenterol 37: 896-904, 2002.

28. Soule HD, Maloney TM, Wolman SR, et al: Isolation and characterization of a spontaneously immortalized human breast epithelial cell line, MCF-10F. Cancer Res 50: 6075-6086, 1990.

29. Tait L, Soule HD and Russo J: Ultrastructural and immunocytochemical characterization of an immortalized human breast epithelial cell line, MCF-10F. Cancer Res 50: 6087-6094, 1990.

30. Calaf G and Hei TK: Establishment of a radiation- and estrogeninduced breast cancer model. Carcinogenesis 21: 769-776, 2000
31. Chen WH, Wei SJ, Liu MJ, Hsiao M, Kou-Lin J and Yang W: Tumor invasiveness and liver metastasis of colon cancer cells correlated with cyclooxygenase-2 (COX-2) expression and inhibited by a COX-2-selective inhibitor, Etodolac. Int J Cancer 91: 894-899, 2001.

32. Sambrook J, Fritsch EF and Maniatis T: Molecular cloning: a laboratory manual. 3rd edition. Cold Spring Harbor, NY. Cold Spring Harbor Laboratory Press, 1989.

33. Woods DB and Vousden KH: Regulation of p53 function. Exp Cell Res 264: 56-66, 2001.

34. El-Deiry WS: Regulation of p53 downstream genes. Semin Cancer Biol 8: 345-357, 1998

35. Prives C and Hall PA: p53 pathway. J Pathol 187: 112-126, 1999.

36. Roy D, Calaf G and Hei TK: Profiling of differentially expressed genes induced by high linear energy transfer radiation in breast epithelial cells. Mol Carcinogen 31: 192-203, 2001.

37. Sehgal A, Keener C, Boynton Al, et al: Isolation and characterization of a novel gene from human gliobastoma multiforme turmor tissue. Int J Cancer 71: 565-572, 1997.

38. Carnero A: Targeting the cell cycle for cancer therapy. Br J Cancer 87: 129-133, 2002.

39. Landberg G: Multiparameter analyses of cell cycle regulatory proteins in human breast cancer: a key to definition of separate pathways in tumorigenesis. Adv Cancer Res 84: 35-56, 2002.

40. Huang YC, Chuang LY and Hung WC: Mechanism underlying non-steroidal anti-inflammatory drug-induced p27 (Kip1) expression. Mol Pharmacology 62: 1515-1521, 2002.

41. Hsu SL, Hsu JW, Liu MC, Chen LY and Chang CD: Retinoic acid-mediated G1 arrest is associated with induction of p27 (Kip1) and inhibition of cyclin-dependent kinase 3 in human lung squamous carcinoma CH27 cells. Exp Cell Res 258: 322-331, 2000.

42. Clarke RA, Kairouz R, Watters D, Lavin MF, Kearsley JH and Lee CS: Up-regulation of ATM in sclerosing adenosis of the breast. Mol Pathol 51: 224-226, 1998.

43. Makino M, Utsunomiya A, Maeda Y, Shimokubo S, Izumo S and Baba M: Association of CD40 ligand expression on HTLV-Iinfected T cells and maturation of dendritic cells. Scand J Immunol 54: 574-581, 2001. 